\title{
THINNING EFFECT ON PLANT GROWTH OF PRUNED EUCALYPT CLONE1
}

\author{
Diego Correa Ramos², Geraldo Gonçalves dos Reis ${ }^{3}$, Maria das Graças Ferreira Reis ${ }^{3}$, Helio Garcia Leite ${ }^{3}$, \\ Jonathan James Stocks ${ }^{4}$ Ana Paula Leite de Lima ${ }^{5}$ e Ronan Soares de Faria ${ }^{6}$
}

\begin{abstract}
A pruned stand of eucalypt clone underwent five thinning treatments with the removal of different proportion of the planted trees, at different ages: a) $0 \%$ - unthinned, b) 35\% at 55 months, c) 35\% at 81 months, d) $70 \%$ at 81 months, removing sprouts in the thinned plant stumps and, e) $70 \%$ at 81 months, without coppice sprouts removal. By the age of 141 months, the Weibull distribution showed higher number of trees in the smallest diameter classes for the unthinned treatment. The $70 \%$ thinning, with thinned coppice sprouts removal, presented higher number of individuals in the largest diameter classes. Height and yield were the smallest with the removal of $70 \%$ of the trees at 81 months, maintaining coppice sprouts. The afterthinning periodic annual increment was greater by thinning $35 \%$ of the trees at 55 months resulting in greater number of trees in the largest diameter classes as compared to the other treatments. Yield was higher for the unthinned treatment. The results of this study indicated that thinning $70 \%$ of the trees at the age of 81 months, with coppice sprout removal, could be recommended to obtain trees of larger diameter for multiproduct.
\end{abstract}

Keywords: Forest yield; Diameter distribution; Eucalypt clone.

\section{EFEITO DO DESBASTE SOBRE O CRESCIMENTO DE PLANTAS DE CLONE DE EUCALIPTO DESRAMADO}

\begin{abstract}
RESUMO - Um povoamento desramado de eucalipto foi submetido a cinco tratamentos de desbaste, com remoção de diferentes proporções das árvores plantadas e idades: a) 0\% não desbastado, b) 35\% aos 55 meses, c) 35\% aos 81 meses, d) 70\% aos 81 meses, removendo a brotação nas cepas desbastadas e e) $70 \%$ aos 81 meses, sem remoção da brotação. Aos 141 meses, segundo a distribuição de Weibull, houve maior número de árvores nas menores classes de diâmetro, no tratamento sem desbaste, e quando ocorreu o desbaste de 70\%, com remoção dos brotos das cepas desbastadas, houve maiores frequências nas maiores classes de diâmetro. A altura e a produção de madeira foram menores com o desbaste de $70 \%$ aos 81 meses, sem remoção da brotação. O incremento periódico anual pós-desbaste foi maior com o desbaste aos 55 meses de 35\% das árvores, resultando em grande número de árvores nas maiores classes de diâmetro, em comparação com os demais tratamentos. A produção de madeira foi maior no tratamento sem desbaste. Os resultados deste estudo indicaram que a remoção de 70\% das árvores na idade aproximada de 81 meses, com remoção da brotação, pode ser recomendada para obter árvores de maior diâmetro, visando multiprodutos.
\end{abstract}

Palavras-chave: Produção florestal; Distribuição de diâmetro; Clone de eucalipto.

\footnotetext{
${ }^{1}$ Recebido em 21.05.2013 aceito para publicação em 11.03.2014.

${ }^{2}$ Companhia Ferroligas Minas Gerais, Pirapora, MG, Brasil. E-mail: <diegoenf@gmail.com>.

${ }^{3}$ Departamento de Engenharia Florestal, Universidade Federal de Viçosa, Viçosa, MG, Brasil. E-mail: <greis@ufv.br>, <mgfreis@ufv.br>e<hgleite@gmail.com>.

${ }^{4}$ Aperam S.A., Timóteo, MG, Brasil.E-mail: <jonathan.stocks@aperam.com>.

${ }^{5}$ Universidade Federal de Mato Grosso do Sul, Chapadão do Sul, MS, Brasil. E-mail: <paula.leite@ufms.br>.

${ }^{6}$ Programa de Pós-Graduação em Ciência Florestal, Universidade Federal de Viçosa, Viçosa, MG, Brasil. E-mail: <ronan.faria@ufv.br>.
} 


\section{INTRODUCTION}

Most planted eucalypt has been exploited up to the age of seven years in Brazil mainly for pulp and charcoal production. In despite of these dominant uses, demand for eucalypt solid wood, free of knots, has been increasing, especially for sawn wood purpose.

The production of high quality eucalypt lumber requires tree pruning and stand thinning. Pruning is necessary to obtain wood without knots (PIRES, 2000; MONTAGU et al., 2003; POLLI et al., 2006). Most Brazilian studies aimed to identify the best way of pruning without reduction in the stand productivity (PIRES, 2000; FINGER et al., 2001; PIRES et al., 2002; VALE et al., 2002; ALMEIDA, 2003; LIMA, 2003; PULROLNIK et al., 2005; CHAVES, 2005; POLLI et al., 2006; STOCKS, 2007; MONTE et al., 2009; FONTAN et al., 2011).

Growth reduction may occur with high removal of photosynthetic area (PINKARD; BEADLE, 1998; PIRES, 2000) and can be avoided with the proper definition of the timing and intensity of pruning, and the selection of genotype with high rates of canopy recovery after pruning (ALMEIDA, 2003; LIMA, 2003; PULRONILK et al., 2005; MONTE et al., 2009; FONTAN et al., 2011). Proper forest management is important to obtain high number of plants in larger diameter classes so that the proportion of clear wood (free of knots) is increased and yield sawing is the maximum possible.

Large diameter logs in pruned eucalypt stands can be obtained with thinning, adding value to the forest, as it increases the amount of wood produced after pruning. This effect depends on the weight of thinning, age of its application, and site quality (GERRAND et al., 1997; SCHNEIDER et al., 1998; NOGUEIRA et al., 2001; CHAVES, 2005; LEITE et al., 2005; DIAS et al., 2005; NOGUEIRA et al., 2005; STOCKS, 2007; TREVISAN et al., 2007; MONTE et al., 2009; DOBNER JR., 2012; FORRESTER; BAKER, 2012; FORRESTER etal., 2012b; SILVAetal., 2012; FORRESTER et al., 2013). Studies highlighting the interaction between artificial pruning and thinning on eucalypt growth are still scarce and recent (GERRAND et al., 1997; CHAVES, 2005; MEDHURST; BEADLE, 2005; STOCKS, 2007; MONTE et al., 2009; FORRESTER; BAKER, 2012; FORRESTER et al., 2012b, 2013).

Thinning promotes increase in the photosynthetic rate mainly in the leaves of the lower and middle strata of the canopy (MEDHURST; BEADLE, 2005). The leaves in these strata are partially self-shaded, and after thinning there is an increase in photosynthetically active radiation transmittance (CHAVES et al., 2007), which favors plant growth. The availability of water and nutrients can also affect the growth of plants after thinning. The leaves removal with the thinning favors the increase in soil water potential (WENG et al., 2007), indicating a greater availability of water to the retained trees. Forrester et al. (2012b) reported that thinning and fertilizer application intensified the effect of pruning on the growth of Eucalyptus nitens.

The aim of this study was to evaluate the effect of thinning on the growth of a pruned Eucalyptus grandis clone stand in the savannah region, Minas Gerais, Brazil.

\section{MATERIALAND METHODS}

This study was conducted in the savannah region, in a stand of Eucalyptus grandis clone identified as 24504-CAF, planted in November/1998 at 3 x 3 m spacing in Abaeté, MG, Brazil (Latitude 19¹5'94"S, Longitude 4544'56" E and average Altitude of $647 \mathrm{~m}$ a.s.l.). The average annual temperature is $22.3^{\circ} \mathrm{C}$, the average temperature of the coldest month is $19.0^{\circ} \mathrm{C}$ and the hottest month is $23.8^{\circ} \mathrm{C}$. The average annual rainfall is $1,350 \mathrm{~mm}$, with average annual water deficit of 142 $\mathrm{mm}$ and annual potential evapotranspiration of 1,216 mm (Monte et al., 2009). The topography of the region varies from flat to gently rolling. The soils in the region are classified as Red Distrophic Latosol (MAPAS, 2013).

The planting area was subsoiled at 50-60 cm depth and 100 g per plant of NPK (6-30-6) enriched with $0.7 \%$ $\mathrm{Cu}, 1 \% \mathrm{~B}$ and $1 \% \mathrm{Zn}$ was applied in the planting hole. Widespread application of the NK (8-32) + 0.7\% B fertilizer occurred 75 days after planting. In October 2001, 100 g per plant of potassium chloride was applied (LIMA, 2003).

Thinning treatments were applied in pruned stands (CHAVES et al., 2007; MONTE et al., 2009; STOCKS, 2007). The missing trees in the stand were considered part of the thinning, avoiding the formation of large gaps in the plots.

Thinning treatments included the removal of 0 (unthinned), 35 and $70 \%$ of the total number of trees in each plot, including tree planting failures. The treatment of 35\% thinning was applied at 55 (35\% 55) or 81 (35\% 81 ) months after planting, with total removal of the stump sprouts from the thinned trees. The treatment 
of $70 \%$ thinning was performed only at 81 months adopting two methods of coppice management: total removal of stump sprouts ( $70 \% 81 \mathrm{NC})$, and thinning to one sprout per stump (70\% $81 \mathrm{WC}$ ). The thinning of $35 \%$ and $70 \%$ based on the number of trees corresponded to 27 and $60 \%$ of the stand basal area. The final number of trees after thinning was 1111, 722 and 330, respectively.

Three soil samples were collected in 2006 in each thinning treatment, at the depths of $0-20 \mathrm{~cm}$ and 20$40 \mathrm{~cm}$ for soil chemical analysis and the results indicate low soil fertility (Table 1 ).

Diameter at $1.3 \mathrm{~m}$ height $(\mathrm{dbh})$ and total height of the trees were measured at 81, 93, 105, 117, 129 and 141 months of age. The outside bark yield was estimated with a volume equation adjusted using data obtained from sampled trees and the Schumacher and Hall (1933) model. After obtaining the volume for each plot and age, the periodic annual increment $(P A I)$ after thinning and the mean annual increment (MAI) were estimated. The $M A I$ was estimated based on the net wood production.

To characterize the diameter distribution, the Weibull probability density function of two parameters was used. This function was selected on the basis of results already obtained for eucalypt plantations (NOGUEIRA, 2003; CAMPOS; LEITE, 2009), as follows:

$$
f(X)=\frac{\gamma}{\beta}\left(\frac{X}{\beta}\right)^{\gamma-1} e^{-\left(\frac{X}{\beta}\right)^{\gamma}}
$$

Where $\beta$ and $\gamma=$ function parameters, $\mathrm{X}=$ random variable, in this case, the center of the diameter class; $f(x)=$ frequency or relative volume per unit area.

The following logistic model was adjusted to estimate production:

$$
Y=\frac{a}{1+b e^{-c X}}+\varepsilon
$$

Where $Y=$ yield $\left(\mathrm{m}^{3} \mathrm{ha}^{-1}\right) ; x=$ age of the stand, in months; $a, b$, and $c=$ model parameters, and $\varepsilon=$ random error, $\mathcal{E}^{\sim N} \mathrm{~N}\left(0, \mathrm{~s}^{2}\right)$.

Identity test models were applied for comparing the production curves obtained for each treatment.

\section{RESULTS}

The growth in diameter, total height, yield, after thinning $P A I$ and $M A I$ differed $(\mathrm{p} \leq 0.05)$ among thinning treatments up to the age of 141 months, considering the average of all trees at each thinning treatment (Table 2).

The plants from the $70 \% 81$ NC treatment showed average $d b h$ of $19.1 \mathrm{~cm}, 15 \%$ greater $(\mathrm{p} \leq 0.05)$ than that observed for the unthinned treatment, and $7.9 \%$ higher ( $\leq \leq 0.05$ ) than the other three thinning treatments. The average increase in diameter after thinning was 2.64 $\mathrm{cm}(19.8 \%)$ and $4.5 \mathrm{~cm}$ (30\%) for the 35\% 81 and 70\% 81 NC treatments. The greater availability of growth resources after thinning promotes an increase in the number of larger diameter class trees, which can be

Table 1 - Soil chemical analysis of the study area at the depths of 0-20 and 20-40 cm, in Abaeté, MG, Brazil.

\begin{tabular}{|c|c|c|c|c|c|c|c|c|c|c|c|c|c|}
\hline \multirow[t]{2}{*}{ Treatments } & \multirow{2}{*}{$\begin{array}{c}\mathrm{pH} \\
\mathrm{H}_{2} \mathrm{O}\end{array}$} & $\mathrm{P}$ & \multirow{2}{*}{$\frac{\mathrm{K}}{\mathrm{m}^{-3}}$} & $\mathrm{Ca}^{2+}$ & $\mathrm{Mg}^{2+}$ & $\mathrm{Al}^{3+}$ & $\mathrm{H}+\mathrm{Al}$ & SB & ECEC & CEC-7 & BS & $\mathrm{m}$ & \multirow{2}{*}{$\begin{array}{c}\mathrm{OM} \\
\text { dag kg-1 }\end{array}$} \\
\hline & & $\mathrm{mg} \mathrm{dm}^{-3}$ & & \multicolumn{4}{|c|}{$\mathrm{cmol} \mathrm{dm}^{-3}$} & \multicolumn{3}{|c|}{$\mathrm{cmol} \mathrm{dm}^{-3}$} & \multicolumn{2}{|c|}{$\%$} & \\
\hline \multicolumn{14}{|c|}{$0-20 \mathrm{~cm}$} \\
\hline $35 \% 55$ & 4.6 & 1.2 & 9.0 & 0.17 & 0.07 & 1.53 & 7.48 & 0.3 & 1.92 & 8.07 & 3.3 & 86 & 1.95 \\
\hline $35 \% 81$ & 4.5 & 1.0 & 7.7 & 0.07 & 0.00 & 1.67 & 7.48 & 0.1 & 1.79 & 7.85 & 1.3 & 95 & 2.00 \\
\hline $70 \% 81 \mathrm{WC}$ & 4.3 & 1.0 & 14.0 & 0.07 & 0.00 & 1.33 & 8.80 & 0.1 & 1.54 & 9.29 & 1.0 & 93 & 2.17 \\
\hline $70 \% 81 \mathrm{NC}$ & 4.5 & 1.0 & 14.3 & 0.00 & 0.00 & 1.50 & 7.26 & 0.0 & 1.54 & 7.30 & 0.3 & 97 & 1.82 \\
\hline $\mathrm{NT}$ & 4.5 & 1.1 & 14.7 & 0.07 & 0.00 & 1.93 & 8.19 & 0.1 & 2.04 & 8.30 & 1.3 & 95 & 2.22 \\
\hline \multicolumn{14}{|c|}{$20-40 \mathrm{~cm}$} \\
\hline $35 \% 55$ & 4.6 & 1.1 & 7.7 & 0.17 & 0.07 & 1.40 & 7.15 & 0.0 & 1.46 & 6.68 & 0.0 & 98 & 1.51 \\
\hline $35 \% 81$ & 4.6 & 0.9 & 5.7 & 0.07 & 0.00 & 1.23 & 6.71 & 0.1 & 1.32 & 6.80 & 1.3 & 93 & 1.28 \\
\hline $70 \% 81 \mathrm{WC}$ & 4.4 & 1.0 & 7.7 & 0.03 & 0.00 & 1.27 & 8.36 & 0.1 & 1.32 & 8.41 & 0.3 & 96 & 1.95 \\
\hline $70 \% 81 \mathrm{NC}$ & 4.6 & 0.9 & 8.0 & 0.03 & 0.00 & 1.30 & 6.49 & 0.1 & 1.36 & 6.55 & 0.7 & 96 & 1.60 \\
\hline NT & 4.6 & 0.9 & 8.0 & 0.00 & 0.00 & 1.43 & 6.66 & 0.1 & 1.58 & 7.29 & 1.3 & 94 & 1.55 \\
\hline
\end{tabular}
Tabela 1 - Análise química de solo da área de estudo nas profundidades de 0-20 e 20-40, em Abaeté, MG, Brasil.

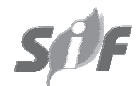

Revista Árvore, Viçosa-MG, v.38, n.3, p.495-503, 2014 
Table 2 - Average diameter $(d b h)$, total height $(H t)$, yield $\left(\mathrm{m}^{3} h \mathrm{a}^{-1}\right)$, after thinning periodic annual increment (IPA) and mean annual increment (MAI), up to 141 months of age, and volume equations $\left(\mathrm{m}^{3} \mathrm{ha}^{-1}\right)$, as a function of age $(A)$, in months, with corresponding coefficients of determination $\left(\mathrm{R}^{2}\right)$, in a pruned stand of the clone 24504 of Eucalyptus grandis submitted to different thinning regimes, in Abaeté, MG, Brazil.

Tabela 2 - Diâmetro à altura do peito (DAP), altura total $(\mathrm{Ht})$, produção $\left(\mathrm{m}^{3} \mathrm{~h} \mathrm{a}^{-1}\right)$, incremento periódico anual após o desbaste (IPA) e incremento médio anual (IMA), até 141 meses de idade, e equações volumétricas $\left(\mathrm{m}^{3} \mathrm{ha} \mathrm{h}^{-1}\right)$, em função da idade (A), em meses, com respectivos coeficientes de determinação $\left(R^{2}\right)$, em um povoamento desramado do clone 24504 de Eucalyptus grandis submetido a diferentes regimes de desbaste, em Abaeté, MG, Brasil.

\begin{tabular}{|c|c|c|c|c|c|c|c|}
\hline Treat. & $\begin{array}{l}d b h \\
\mathrm{~cm}\end{array}$ & $\begin{array}{l}\text { Ht } \\
\text { m }\end{array}$ & $\begin{array}{c}\text { Yield } \\
\text { mha }^{3} \mathbf{h a}^{-1}\end{array}$ & $\begin{array}{c}P A I \\
\mathrm{~m}^{3} \mathrm{ha}^{-1} \mathrm{yr}^{-1}\end{array}$ & $\begin{array}{c}\text { MAI } \\
\mathrm{m}^{3} \mathrm{ha}^{-1} \mathrm{yr}^{-1}\end{array}$ & Equation & $R^{2}$ \\
\hline $35 \% 55$ & $17.7 \mathrm{~b}$ & $24.0 \mathrm{a}$ & $204.1 \mathrm{~b}$ & $20.4 \mathrm{a}$ & $19.0 \mathrm{~b}$ & $y=212,4755 /\left(1+22,7233 e^{-0,0432 A}\right)$ & 0.80 \\
\hline $35 \% 81$ & $17.7 \mathrm{~b}$ & 23.8 a & $164.0 \mathrm{c}$ & $10.4 \mathrm{c}$ & $16.4 \mathrm{c}$ & $y=165,4628 /\left(1+24,0925 e^{-0,0484 A}\right)$ & 0.91 \\
\hline $70 \% 81 \mathrm{WC}$ & $17.6 \mathrm{~b}$ & $23.1 \mathrm{~b}$ & $84.4 \mathrm{e}$ & $5.6 \mathrm{e}$ & $13.8 \mathrm{~d}$ & $y=87,9472 /\left(1+12,8401 e^{-0,03857 A}\right)$ & 0.88 \\
\hline $70 \% 81 \mathrm{NC}$ & $19.1 \mathrm{a}$ & $24.5 \mathrm{a}$ & $112.4 \mathrm{~d}$ & $9.9 \mathrm{~d}$ & $16.5 \mathrm{c}$ & $y=130,0097 /\left(1+11,8253 e^{-0,03156 A}\right)$ & 0.82 \\
\hline NT & $16.6 \mathrm{c}$ & $24.5 \mathrm{a}$ & 238.5 a & $16.0 \mathrm{~b}$ & 20.3 a & $y=247,9662 /\left(1+20,7029 e^{-0,0457 A}\right)$ & 0.79 \\
\hline
\end{tabular}

Averages with the same letters in each column do not differ $(\mathrm{p}>0.05)$ by the Tukey test.

$\mathrm{R}^{2}=\left(\mathrm{R}_{\mathrm{Yv}}\right)^{2} ; Y=\mathrm{m}^{3} \mathrm{ha}^{-1} ; e=$ exponential; and $A=$ age in months.

evidenced by the displacement of the Weibull distribution curves to the right in the thinned treatments (Fig. 1). A $27 \%$ reduction of the basal area at 81 months (35\% 81) was not sufficient to promote ingrowths in the largest diameter classes. Moreover, the light thinning applied at the age of 55 months, when plants are more responsive to interference in the stand, promoted substantial change in the diameter distribution.

The highest yield ( $238.5 \mathrm{~m}^{3} \mathrm{ha}^{-1}$ ) was obtained for the unthinned treatment (Table 2). The yield of the $35 \%$ thinning at 55 months (27\% basal area removal) was $24.3 \%$ greater than the $35 \%$ thinning applied at 81 months.

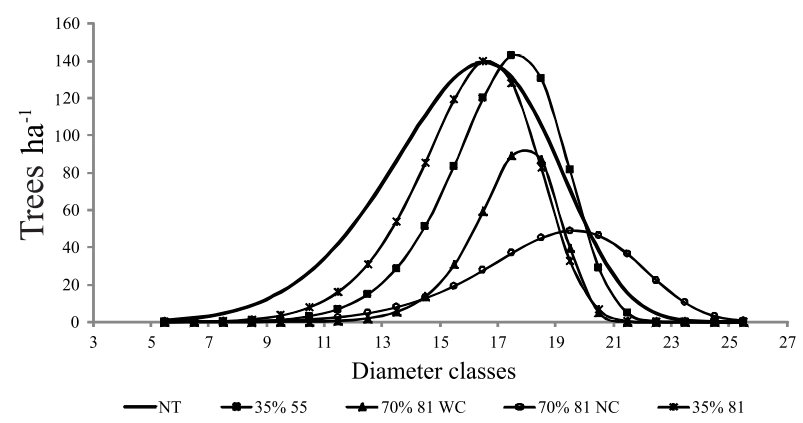

Figure 1 - Frequency of trees per hectare, at the age of 141 months, estimated by the Weibull distribution fitted to data from a pruned stand of the 24504 clone of Eucalyptus grandis submitted to different thinning regimes, in Abaeté, MG, Brazil.

Figura 1 - Frequência de árvores por hectare, com a idade de 141 meses, estimadas pela distribuição Weibull ajustada aos dados de um povoamento desramado do clone 24504 de Eucalyptus grandis submetido a diferentes regimes de desbaste, em Abaeté, MG, Brasil.
By comparing the $70 \% 81 \mathrm{WC}$ and $\mathrm{NC}$ thinning treatments, it was observed coppice interference on retained trees, reducing their average diameter and, consequently, their distribution into higher diameter classes. The average plant height for this treatment was the smallest $(\mathrm{p} \leq 0.05)$ (Table 2). The maintenance of coppice significantly affected the production of the retained trees after thinning. The total yield (retained trees + coppice) obtained in the treatment $70 \% 81$ WC was lower than that for the $70 \% 81$ NC treatment (Fig. 2).



Figure 2 - Growth curves estimated by the logistic regression model for a pruned Eucalyptus grandis clone stand submitted to $70 \%$ thinning at 81 months, with (WC) and without (NC) the presence of coppice sprouts, in Abaeté, MG, Brazil (RT - retained trees only, $\mathrm{RT}+\mathrm{CS}$ - retained trees + coppice sprouts).

Figura 2 - Curvas de crescimento estimadas pelo modelo de regressão logística para um povoamento desramado de clone de Eucalyptus grandis submetido a 70\% de desbaste aos 81 meses, com (WC) e sem (SB) a presença de brotos, em Abaeté, MG, Brasil ( $R T$ - somente árvores remanescentes, $R T+C S-$ árvores remanescentes + brotação). 
The periodic annual increment after thinning in the $35 \% 55$ thinned stand was $27.5 \%$ higher $(\mathrm{p} \leq 0.05$ ) than the unthinned stand (Table 2). The unthinned stand attained $M A I$ and yield higher $(\mathrm{p} \leq 0.05)$ than the thinned one. The technical rotation age was slightly higher for the $35 \% 55$ and $70 \% 81$ NC. In these treatments, growth stagnation occurred at 105 months, while for the other treatments this stagnation occurred at approximately 92 months. The growth equations for each treatment are presented in Table 2 and the growth curves in Fig. 3.

Plant mortality did not differ ( $p>0.05$ ) between the thinned and unthinned stands. There is only a trend of increasing mortality in the unthinned stand, indicating that intraspecific competition was kept high in that treatment.

\section{DISCUSSION}

Concerning the increase in tree $d b h$ with thinning as compared to the unthinned treatments, this result has also been reported by other authors. Silva et al. (2012) observed an increase of 14.2\% in diameter 36 months after a 50\% reduction in basal area in 89 months old eucalypt plantation. Pinus taeda thinned at the age of 132 months presented an increase of $37.4 \%$ in diameter 72 months after thinning (ELESBÃO; SCHNEIDER, 2011). Trevisan et al. (2007) found no effect of $70 \%$ basal area thinning on the dominant trees diameter but an increase of up to $38 \%$ for the average trees was observed when compared to an unthinned Eucalyptus grandis stand. Gerrand et al. (1997) found no effect of thinning on the 100 dominant trees but the response of thinning on diameter and yield was positive when the best 300-400 trees/ha were analyzed. These responses indicate that the maintenance of intermediate sized trees after the first thinning result in larger wood yield in the subsequent thinning.

When a light thinning is applied at earlier ages, it is required a further thinning in more advanced ages to maintain continuous growth of the retained trees. (MONTE et al., 2009). Thus, the production of at least one pruned basal log with higher diameter for sawn timber production in the treatment 35\% 55 could be achieved with the completion of a second thinning.

A $27 \%$ reduction of the basal area at 81 months (35\% 81) was not sufficient to promote ingrowth in the largest diameter classes. Moreover, the light thinning
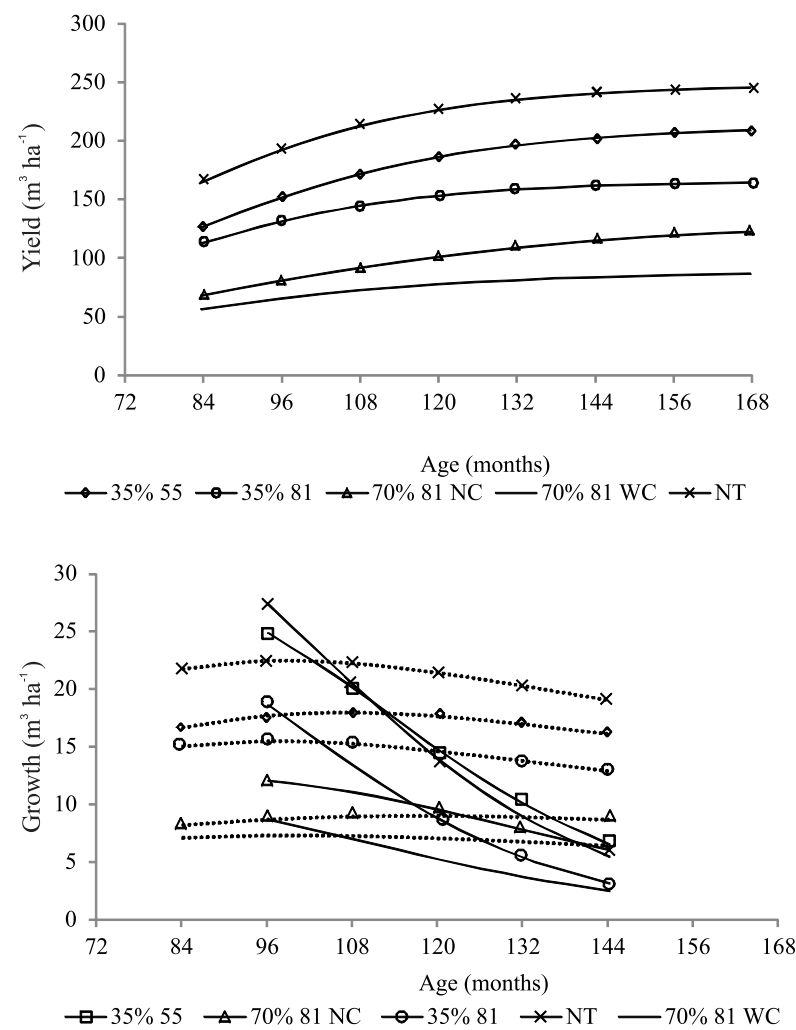

Figure 3 - Net production curves $\left(\mathrm{m}^{3} \mathrm{ha}^{-1}\right)$, growth rate $\left(\mathrm{m}^{3} \mathrm{ha} \mathrm{a}^{-1}\right)$ and mean annual increment $\left(\mathrm{m}^{3} \mathrm{ha}^{-1} \mathrm{yr}^{-1}\right)$ for pruned stand of Eucalyptus grandis 24504 clone submitted to thinning regimes, in Abaeté, MG Brazil. MAI(rem.) = mean annual increment of retained trees; and CAI $($ rem. $)=$ current annual increment of retained trees.

Figura 3 - Curvas de produção líquida $\left(\mathrm{m}^{3} \mathrm{ha}^{-1}\right)$, taxa de crescimento $\left(\mathrm{m}^{3} h \mathrm{a}^{-1}\right)$ e incremento médio anual $\left(\mathrm{m}^{3} \mathrm{ha}^{-1} \mathrm{ano}^{-1}\right)$ para povoamento desramado do clone 24504 de Eucalyptus grandis submetido a regimes de desbaste, em Abaeté, MG, Brasil. IMA(rem.) = incremento médio anual de árvores remanescentes; e ICA(rem.) = incremento corrente anual de árvores remanescentes.

applied at the age of 55 months, when plants are more responsive to interference in the stand, promoted substantial change in the diameter distribution. Usually some trees of low quality stem, which are removed with thinning, may be dominant trees. If they are retained in the stand until older ages, this results in greater competition with the trees that should be managed for high quality timber production (GERRAND et al., 1997).

Revista Árvore, Viçosa-MG, v.38, n.3, p.495-503, 2014 
The increase in growth resources after thinning favors the growth of the retained trees (ASSMANN, 1970). According to Paula et al. (2013) there is a decrease in diameter with the increasing proximity of plants in the planting line due to greater competition between plants, even if there is a large distance between tree planting rows. Thus, an increasing effectiveness of the thinning treatments depends on its weight and on plant distribution after thinning. However, heavy thinning or low planting density can result in disproportionate increase of canopy, mainly branches, to the detriment of the growth of the stem (SCHNEIDER et al., 1998; LELES et al., 2001; FORRESTER et al., 2012b).

Coppice interference on retained trees can be observed, reducing their average diameter, the distribution into higher diameter classes and in the final yield, when the $70 \% 81$ WC and 70\% 81 NC treatments are compared. The highest frequency of trees per hectare in the largest diameter classes in the $70 \% 81 \mathrm{NC}$ thinning treatment evidences the importance of removing the sprouts from the stumps of the harvested trees. The reduced plant height for the $70 \% 81 \mathrm{WC}$ treatment (Table 2) also denotes the competition between coppice and retained trees in the stand, as for the other treatments the plant height values were similar. The competition between coppice and the retained plants may have been intensified by the low carrying capacity of the site, with aluminum saturation over $85 \%$ and very low base saturation (Table 1 ). Coppice sprouts benefit from established root system, which favors the rapid initial growth of the shoot, producing high leaf area (REIS; KIMMINS, 1986; OLIVEIRA et al., 2008). Also, the coppice sprout leaves have a higher number of stomata and stomatal conductance as compared to the intact plants (BLAKE, 1980; REIS; REIS, 1991; FORRESTER et al., 2003), which means that the competition with the retained plants is more intense. Forrester et al. (2012a) observed an 11\% increase in basal area of the 200 largest diameter trees when there was total removal of stump sprouts after thinning stands planted with Eucalyptus globulus.

The high yield obtained in the unthinned treatment is important if the forest is managed for charcoal, pulp and paper and other products. If the forest is managed by applying pruning and thinning for high quality wood production for sawn logs and furniture, other characteristics, especially diameter, are more important than yield. The growth in diameter added after pruning

Revista Árvore, Viçosa-MG, v.38, n.3, p.495-503, 2014 (diameter over stubs) represents the clear wood (MONTAGU et al., 2003; POLLI et al., 2006). Therefore, one should manage the stand to obtain the maximum yield of large diameter trees, adding much greater value to the forest. In the 35\% 55 thinning treatment (27\% removal of basal area), the yield was $24.3 \%$ higher than when thinning was applied at 81 months. It is likely that there has been greater tree mortality in the latter treatment due to more intense competition with the increasing age of the stand. There is consensus that the thinning should be done just before the start of the stagnation of the competition between the retained trees (LEITE et al., 2008). And a later thinning treatment should be applied if an early (pre-commercial) thinning is adopted, and the trees removed from this later thinning should attain diameter large enough to produce at least one basal log of high quality wood, increasing the rate of return on the investment, if adequate pruning is adopted.

By maintaining coppice sprouts in the thinned trees, total yield (retained trees + coppice) was lower than that for the $70 \% 81$ NC treatment. This fact is explained by the high mortality rate of the stump sprouts resulting in low coppice yield. The mortality rate increased 24 months after thinning, and reached 35.7\% 60 months after thinning. The possible explanation for the high coppice mortality is the competition with the retained plants primarily in relation to radiation, since the eucalypt genotype studied is highly light demanding.

Growth response after thinning, as can be analyzed from the periodic annual increment after thinning, is important to help taking decision about the best management scenario to obtain a higher yield of quality wood. The 35\% 55 thinned stand attained the highest $P A I$. This response indicates that thinning at younger ages is recommended for increased production of the retained trees. A similar result was reported by Monte et al. (2009). A second thinning applied approximately at the age of 105 months, before growth stagnation after first thinning, could enhance the wood production and quality and increase profitability.

Plant mortality did not differ between the thinned and unthinned stands. There is only a trend of increasing mortality in the unthinned stand, indicating that intraspecific competition was kept high in that treatment. One purpose of thinning is to anticipate the mortality of trees that die naturally in the stand (CAMPOS and 
LEITE, 2009). As the population becomes older, high density planting accentuates the growth resource limitations which favor the mortality of dominated individuals. The death of trees is slow at first and then becomes faster and more intense, which explains natural selection, where individuals that are more vigorous and better adapted to the environment keep growing, with greater chances of survival (SMITH et al., 1997).

\section{CONCLUSIONS}

All thinning treatments applied to the pruned eucalypt clone stand increased the frequency of trees in the largest diameter classes at older ages, which implies in greater clear wood production and greater value of the wood produced. The $70 \%$ thinning at 81 months, with coppice sprouts removal, presented the highest number of individuals in the largest diameter classes, which indicates that this thinning treatment could be recommended to obtain trees of larger diameter for multiproduct.

To maintain continuous growth of the retained trees when a light first thinning is applied in young stands, there is a need for further thinning in more advanced ages. Thus, larger diameter increment could be achieved with the completion of a second thinning when 35\% of the planted trees is removed at the age of 55 months.

Coppice from the stumps of the trees removed by thinning has a negative effect on the growth of the retained trees and should not be maintained after thinning.

\section{ACKNOWLEDGMENTS}

To Fundação de Amparo à Pesquisa do Estado de Minas Gerais (FAPEMIG), Conselho Nacional de Desenvolvimento Científico e Tecnológico (CNPq), Coordenação de Aperfeiçoamento do Pessoal de Nível Superior (CAPES), Universidade Federal de Viçosa (UFV), and ArcelorMittal BioFlorestas for supporting this study, both in field and lab settings.

\section{REFERENCES}

ALMEIDA, M. L. Desrama artificial em clones de híbridos de Eucalyptus grandis $x E$. urophylla com diferenças em arquitetura de copa. 2003. 119f. Dissertação ( Mestrado em Ciência Florestal) - Universidade Federal de Viçosa, Viçosa, MG, 2003.
ASSMANN, E. The principles of forest yield study. New York: Pergamon Press, 1970. 560p.

BLAKE, T. J. Effects of coppicing on growth rates, stomatal characteristics and water relations in Eucalyptus camaldulensis Dehn. Australian Journal of Plant Physiology, v.7, n.1, p.81-84, 1980.

CAMPOS, J. C. C.; LEITE, H. G. Mensuração florestal: perguntas e respostas. 3.ed. Viçosa, MG: Universidade Federal de Viçosa, 2009. 548p.

CHAVES, R. A. Dinâmica de copa e crescimento de plantas de clone de Eucalyptus grandis W. Hill ex Maiden submetidas a desrama artificial e a desbaste. 2005. 68f. Dissertação (Mestrado em Ciência Florestal) - Universidade Federal de Viçosa, Viçosa, MG, 2005.

CHAVES, R. A. et al. Dinâmica de cobertura de dossel de povoamento de clone de Eucalyptus grandis W. Hill ex-Maiden submetidos a desrama artificial e desbaste. Revista Árvore, v.31, n.6, p.989-998, 2007.

DIAS, A. N. et al. Emprego de um modelo de crescimento e produção em povoamentos desbastados de eucalipto. Revista Árvore, v.29, n.5, p.731-739, 2005.

DOBNER, M. JR.; HIGA, A. R.; URBANO, E. Determinação da idade e intensidade ótimas para realização do primeiro desbaste em um povoamento de Eucalyptus dunnii. Floresta, v.42, n.3, p.485-494, 2012.

ELESBÃO, L. E. G.; SCHNEIDER, P. R. Produção de Pinus taeda L. em povoamento desbastado na região de Campos de Cima da Serra, Rio Grande do Sul. Ciência Florestal, v.21, n.1, p.119-124, 2011.

FINGER, C. A. G. et al. Efeito da intensidade de desrama sobre o crescimento e a produção de Eucalyptus saligna Smith. Cerne v.7, n.1, p.5364, 2001.

FONTAN, I. C. I. et al. Growth of pruned eucalypt clone in an agroforestry system in southeastern Brazil. Agroforestry Systems, v.83, n.1, p.121-131, 2011.

Revista Árvore, Viçosa-MG, v.38, n.3, p.495-503, 2014 
FORRESTER, D. I.; ELMS, S. R.; BAKER, T. G. Tree growth-competition relationships in thinned Eucalyptus plantations vary with stand structure and site quality. European

Journal of Forest Research, v.132, n.2, p.241-252, 2013.

FORRESTER, D. I.; BAKER, T. G. Growth responses to thinning and pruning in Eucalyptus globulus, Eucalyptus nitens, and Eucalyptus grandis plantations in southeastern Australia. Canadian Journal of Forest Research, v.42, n.1, p.75-87, 2012.

FORRESTER, D. I.; BAUHUS, J.; CONNELL, M. Competition in thinned silvertop ash (Eucalyptus sieberi L. Johnson) stands from early coppice growth. Forest Ecology and Management, v.174, n.1-3, p.459-475, 2003.

FORRESTER, D. I.; BERTRAM, C. A.; MURPHY, S. Impact of competition from coppicing stumps on the growth of retained trees differs in thinned Eucalyptus globulus and Eucalyptus tricarpa plantations in southeastern Australia.

Canadian Journal of Forest Research, v.42, n.5, p.841-848, 2012a.

FORRESTER, D. I. et al. Interactive effects of simultaneously applied thinning, pruning and fertilizer application treatments on growth, biomass production and crown architecture in a young Eucalyptus nitens plantation.

Forest Ecology and Management, v.267, p.104-116, 2012b.

GERRAND, A. M.; NEILSEN, W. A.; MEDHURST, J. L. Thinning and pruning eucalypt plantations for sawlog production in Tasmania. Tasforests, v.9, p.15-34, 1997.

LEITE, H. G. et al. Avaliação de um modelo de distribuição diamétrica ajustado para povoamento de Eucalyptus sp. submetidos a desbaste. Revista Árvore, v.29, n.2, p.271-280, 2005.

LEITE, H. G. et al. Uso da mensuração florestal em pesquisa e em manejo de povoamentos submetidos a desbaste. In: SEMINÁRIO SOBRE SILVICULTURA EM FLORESTAS PLANTADAS, 3., 2008, Belo Horizonte. Anais... Belo Horizonte: 2008. p.77-84.

Revista Árvore, Viçosa-MG, v.38, n.3, p.495-503, 2014
LELES, P. S. S. et al. Crescimento, produção e alocação de matéria seca de Eucalyptus camaldulensis e E. pellita sob diferentes espaçamentos na região de cerrado, MG. Scientia Forestalis, n.59, p.77-87, 2001.

LIMA, A. P. L. Desrama artificial em clone de Eucalyptus grandis (HILL ex MAIDEN): efeitos sobre o crescimento, a dinâmica de copa e o tempo de desrama. 2003. 195f. Tese (Doutorado em Ciência Florestal) - Universidade Federal de Viçosa, Viçosa, MG, 2003.

MAPAS e manuais de solos do Estado de Minas Gerais. http://www.feam.br/noticias/1/949-mapasde-solo-do-estado-de-minas-gerais. Access: 18 de out. 2013.

MEDHURST, J. L.; BEADLE, C. L. Photosynthetic capacity and foliar nitrogen distribution in Eucalyptus nitens is altered by high-intensity thinning. Tree Physiology, v.25, n.8, p.981991, 2005.

MONTAGU, K. D.; KEARNEY, D. E.; SMITH, R. G. B. The biology and silviculture of pruning planted eucalypts for clear wood production: a review.

Forest Ecology and Management, v.179, n.1, p.1-13, 2003.

MONTE, M. A. et al. Crescimento de um clone de eucalipto submetido a desrama e desbaste.

Revista Árvore, v.33, n.8, p.777-787, 2009.

NOGUEIRA, G. S. Modelagem do crescimento e da produção de povoamentos de Eucalyptus sp. e de Tectona grandis submetidos a desbaste. 2003. 132f. Tese (Doutorado em Ciência Florestal) - Universidade Federal de Viçosa, Viçosa, MG, 2003.

NOGUEIRA, G.S. et al. Modelo de distribuição diamétrica para povoamentos de Eucalyptus sp. submetidos a desbaste. Revista Árvore, v. 29, n.4, p.579-589, 2005.

NOGUEIRA, G. S. et al. Determinação da idade técnica de desbaste em plantações de eucalipto, utilizando o método dos ingressos percentuais. Scientia Forestalis, n.59, p.51-59, 2001. 
OLIVEIRA, C. H. R. et al. Área foliar e biomassa de plantas intactas e de brotações de plantas jovens de clone de eucalipto em sistemas agrossilvipastoris. Revista Árvore, v.32, n.1, p.59-68, 2008.

PAULA, R. R. et al. Eucalypt growth in monoculture and silvopastoral systems with varied tree initial densities and spatial arrangements. Agroforestry Systems, v.87, n.6, p.1295-1307, 2013.

PINKARD, E. A.; BEADLE, C. L. Effects of green pruning on growth and stem shape of Eucalyptus nitens (Deane and Maiden) Maiden. New Forests, v.15, p.107-126, 1998.

PIRES, B. M. Efeito da desrama artificial no crescimento e qualidade da madeira de Eucalyptus grandis para serraria. 2000. 91f. Dissertação (Mestrado em Ciência Florestal) - Universidade Federal de Viçosa, Viçosa, MG, 2000.

PIRES, B. M.; REIS, M. G. F.; REIS, G. G. Crescimento de Eucalyptus grandis submetido a diferentes intensidades de desrama artificial na região de Dionísio. Brasil Florestal, v.73, p.13-21, 2002.

POLLI, H. Q. et al. Qualidade da madeira em clone de Eucalyptus grandis Hill ex Maiden submetido a desrama artificial. Revista Árvore, v.30, n.4, p.557-566, 2006.

PULROLNIK, K. et al. Crescimento de plantas de clone de Eucalyptus grandis [Hill ex maiden] submetidas a diferentes tratamentos de desrama artificial, na região de cerrado. Revista Árvore, v.29, n.4, p.495-505, 2005.

REIS, G. G.; REIS, M. G. F. Respostas estomáticas e mudanças nos níveis de reservas de plantas intactas e de brotações de Eucalyptus camaldulensis Dehn. submetidas à deficiência hídrica no solo. Revista Árvore, v.15, n.2, p.111-125, 1991.
REIS, M. G. F.; KIMMINS, J. P. Importância do sistema radicular no crescimento inicial de brotos de Eucalyptus spp. Revista Árvore, v.10, n.2, p.196-201, 1986.

SCHNEIDER, P. R. et al. Produção de Eucalyptus grandis Hill ex maiden em diferentes intensidades de desbaste. Ciência Florestal, v.8, p.129140, 1998.

SCHUMACHER, A. X.; HALL, F. S. Logarithmic expression of timber volume. Journal of Agricultural Research, v.47, n.9, p.719-734, 1933.

SILVA, J. V. et al. Produção e acúmulo de nutrientes em povoamento de eucalipto em consequência da intensidade do desbaste e da fertilização. Pesquisa Agropecuária Brasileira, v.47, n.11, p.1555-1562, 2012.

SMITH, D. M. et al. The practice of silviculture: applied forest ecology. 9.ed. New York: J. Wiley, 1997. 539p.

STOCKS, J. J. Dinâmica de copa, crescimento e viabilidade econômica de um povoamento de eucalipto submetido a desrama e desbaste. 2007. 77f. Dissertação (Mestrado em Ciência Florestal) Universidade Federal de Viçosa, Viçosa, MG, 2007.

TREVISAN, R. et al. Efeito da intensidade de desbaste nas características dendrométricas e Tecnológicas da madeira de Eucalyptus grandis. Ciência Florestal, v.17, n.4, p.377-387, 2007.

VALE, R. S. et al. Efeito da desrama artificial na qualidade da madeira de clones de eucalipto, em sistema agrossilvipastoril. Revista Árvore, v.26, n.3, p.285-297, 2002.

WENG, S. H. et al. Microclimatic responses to different thinning intensities in a Japanese cedar plantation of northern Taiwan. Forest Ecology and Management, v.241, n.1, p.91-100, 2007. 